\title{
SUBTITUSI TEPUNG BLEWAH (Cucumis meloL.Var Cantapulensis) PADA PRODUK MIE BASAH
}

\author{
Substitution Of Blewah Flour (Cucumis Melo.Var Cantalupensis) On Wet Mie Products
}

\author{
Isye Selvianti ${ }^{1}$, Ningrum Dwi Hastuti ${ }^{2}$, \\ ${ }^{1}$ Staf Pengajar Pengelolaan Hasil Perkebunan \\ ${ }^{2}$ Politeknik Negeri Ketapang \\ Email: elpridasihaan91@gmail.com
}

\begin{abstract}
ABSTRAK
Blewah (Cucumis melo L.var cantalupensis.) adalah tumbuhan penghasil buah yang banyak digunakan sebagai minuman penyegar di Asia Tenggara. Blewah sejenis dengan melon namun berbeda kelompok budidaya. Penelitian ini bertujuan untuk mengetahui proses pembuatan mie basah dengan subtitusi tepung blewah dan bagaimana pengaruh penambahan tepung terigu dan tepung blewah pada pembuatan mie basah terhadap daya elastisitas dan tingkat kesukaan konsumen. Metode yang digunakan dalam penelitian ini adalah pembuatan mie basah menggunakan tiga perlakuan yaitu: 50\%, 20\%, dan 30\%, untuk mengetahui parameter uji elastisitas mie basah dan tingkat kesukaan terhadap rasa, warna, dan aroma. Hasil uji elatisitas mie diperoleh hasil untuk perlakuan $50 \%$ tepung blewah yaitu 19\%, 20\% tepung blewah $22 \%$ dan $30 \%$ yaitu 6,67\% dan uji organoleptik pada ketiga variasi penambahan tepung blewah adalah $50 \%$ nilai kesukaan rasa, aroma, dan warna berturut-turut adalah 5,2, 5,8, 5,68, untuk sampel 30\% nilai rata-rata kesukaan rasa, warna, dan aroma berturut-turut adalah 5,16, 5,64 dan 5,92 sedangkan untuk sampel 20\% nilai rata-rata kesukaan rasa, aroma, dan warna berturut-turut adalah 4,56, 6,04 dan 4,88. Kesimpulan dari penelitian ini yaitu penambahan tepung blewah terhadap mie basah berpengaruh terhadap elastisitas mie dan tingkat kesukaan konsumen.

Kata kunci : Blewah, Mie Basah, Elastisitas, Organoleptik
\end{abstract}

\section{ABSTRACT}

Cantaloupe (Cucumis melo L.var cantalupensis.) Is a fruit-producing plant that is widely used as a refreshing drink in Southeast Asia. Cantaloupe is a kind of melon but is different from the cultivation group. This study aims to determine the process of making wet noodles with cantaloupe flour substitution and how the effect of adding flour and cantaloupe flour on the manufacture of wet noodles to the power of elasticity and the level of consumer preference. The method used in this study was the manufacture of wet noodles using three treatments, namely: 50\%, 20\%, and 30\%, to determine the parameters of the elasticity test of wet noodles and the level of preference for taste, color, and aroma. The results of the elasticity test of noodles obtained results for the treatment of 50\% cantaloupe namely 19\%, $20 \%$ cantaloupe $22 \%$ and $30 \%$ namely $6.67 \%$ and organoleptic tests on the three variations of addition of cantaloupe flour were $50 \%$ the value of taste, aroma, and color 5.2, 5.8, 5.68 respectively, for a sample of $30 \%$ the average value of taste, color, and aroma were respectively 5.16, 5.64 and 5.92 while for sample $20 \%$ the average value of 
taste, aroma, and color are respectively 4.56, 6.04 and 4.88. The conclusion of this study is that the addition of cantaloupe flour to wet noodles affects the elasticity of noodles and the level of consumer preference.

Key words: cantaloupe, wet noodles, elasticity, organoleptics

PENDAHULUAN

Indonesia merupakan negara tropis

yang kaya akan buah-buahan, berbagai macam jenis buah-buahan dapat tumbuh subur. Banyak buah-buahan yang sengaja ditanam untuk dikonsumsi sebagai penambah gizi dan vitamin tubuh serta bersifat menyegarkan tubuh. Masyarakat mengkonsumsi buah-buahan tersebut dengan berbagai cara seperti dikonsumsi langsung, diolah menjadi es buah, cocktail, ataupun hanya ditambahkan gula (Sunarjono dan Ramayulis, 2012). Namun, daya tahan buah setelah pasca panen yang tidak tepat akan mengakibatkan kualitas buah menurun,maka dari itu perlu pengolahan pasca panen yang tepat sehingga kualitas buah tidak menurun dan buah bisa dipasarkan.

Blewah (cucumis melo L.) banyak mengandung beta karoten (karotenoid) yang diubah menjadi provitamin A, kurang lebih sepertiga dari karotenoid dalam makanan akan diubah menjadi vitamin A. Fungsi beta karoten dalam blewah akan sama dengan fungsi vitamin A, yaitu berperan dalam berbagai fungsi bagi tubuh, seperti penglihatan, differensiasi sel, kekebalan, pertumbuhan dan perkembangan, reproduksi serta pencegahan kanker dan penyakit jantung. Kemampuan vitamin A mempengaruhi perkembangan sel epitel dan kemampuan meningkatkan aktivitas sistem kekebalan diduga berpengaruh dalam pencegahan kanker, terutama kanker kulit, tenggorokan, paru-paru, payudara, dan kantung kemih (Sunarjono et al, 2012).

Buah blewah tidak tahan lama maka perlu dilakukan penanganan lebih lanjut setelah panen. Salah satu penanganan yang dapat dilakukan adalah membuat tepung dari buah blewah dan olahan seperti pembuatan mie basah.

Mie basah merupakan jenis mie yang mengalami proses perebusan dan memiliki kadar air sebesar 35\% (Astawan,2006). Mie merupakan produk pangan yang sering dikonsumsi oleh sebagian besar masyarakat baik anak-anak, remaja maupun orang tua baik sebagai menu sarapan maupun sebagai selingan. Bahan baku pembuatan mie adalah tepung terigu yang berasal dari biji gandum. 
Kebutuhan terigu di Indonesia mengalami peningkatan, tahun2016 meningkat menjadi 5,91 juta ton.

Meningkatnya permintaan terigu dikarenakan semakin beragamnya produk makanan berbasis terigu. Akibatnya ketika harga terigu naik para produsen makanan olahan menghadapi masalah yang berat. Salah satu solusi untuk mengatasi masalah tersebut adalah memanfaatkan bahan pangan untuk substitusi tepung terigu, yaitu blewah. Berdasarkan latar belakang tersebut diatas maka penulis tertarik untuk membuat subtitusi tepung blewah terhadap produk mie basah.

\section{BAHAN DAN METODE}

\section{Alat dan BahanPenelitian}

Alat-alat yang digunakan yaitu baskom, nampan,timbangan analitik, pencetak mie,dandang, kompor gas, sendok, dan mixer. Bahan yang digunakan ialah, tepung terigu, tepung blewah, air, telur, garam, minyak goreng, soda kue.

\section{Prosedur Penelitian}

Prosedur pembuatan mie basah meliputi 4 tahap, yaitu persiapan bahan baku, pencampuran bahan, pencetakan dan

perebusan mie basah. Bahan-bahan dalam pembuataan mie basah yang terdiri dari terigu, dengan perbandingan 50\%:50\%, 80\%:20\%, 70\%:30\% masing-masing dimasukkan kedalam baskom yang berbeda dan diaduk rata, kemudian ditambahkan garam, telur, dan air sedikit demi sedikit sambil diaduk rata hingga terbentuk adonan yang homogen. Adonan selanjutnya diuleni sampai menjadi kenyal dan kalis. Bahan yang sudah tercampur dibuat adonan sampai kalis kemudian didiamkan selama 15 menit. Selanjutnya pembentukan lembaranuntuk kemudian dicetak dengan pencetak mie. Proses yang terakhir adalah perebusan atau pengukusan. Uji organoleptik dilakukan untuk mengetahui tingkat penerimaan panelis terhadap sampel mi basah matang dengan tiga parameter penilaian, yaitu warna, aroma, rasa. Uji organoleptik ini menggunakan 25 orang panelis. Skala yang digunakan pada uji hedonik yaitu : (1) amat sangat tidak suka, (2)sangat tidak suka, (3) tidak suka, (4) agak tidak suka, dan (5) netral, (6) agak suka, 7) suka, (8) sangat suka, (9) amat sangat suka. 
HASIL DAN PEMBAHASAN

\section{Hasil Pengamatan}

Perbandingan substitusi tepung terigu dan tepung blewah pada pembuatan mie basah tepung blewah yang digunakan adalah 50:50, 80:20, dan 70:30. Hasil uji elastisitas dan uji organoleptik mie basah dengan substitusi tepung blewah dapat dilihat pada tabel dibawah ini. Hasil uji elastisitas atau daya tarik pada mie basah tepung blewah dapat dilihat pada Tabel 1, sedangkan hasil uji mengenai uji organoleptik pada mie basah tepung blewah dapat dilihat pada Tabel 2.

Tabel 1 Hasil Elastisitas Mie Basah

\begin{tabular}{|c|c|}
\hline Sampel & \multirow{2}{*}{ Elastisitas \% } \\
\hline Tepung terigu : Tepung blewah & $19 \%$. \\
\hline $50 \%: 50 \%$ & $22 \%$ \\
\hline $80 \%: 20 \%$ & $6,67 \%$ \\
\hline $70 \%: 30 \%$ & \\
\hline
\end{tabular}

Tabel 2. Hasil Pengamatan Organoleptik Mie Basah Subtitusi Tepung Blewah

\begin{tabular}{|c|c|c|c|}
\hline Sampel & \multicolumn{3}{|c|}{ Uji Hedonik } \\
\cline { 2 - 4 } Tepung terigu:Tepung blewah & Rasa & Aroma & Warna \\
\hline $50 \%: 50 \%$ & 5,2 & 5,8 & 5,68 \\
\hline $80 \%: 20 \%$ & 5,16 & 5,64 & 5,92 \\
\hline $70 \%: 30 \%$ & 4,56 & 6,04 & 4,88 \\
\hline
\end{tabular}

\section{PEMBAHASAN}

\section{Elastisitas Mie}

Berdasarkan Tabel 4.1 dapat dilihat elastisitas mie, semakin besar penambahan tepung blewah maka elastisitasnya rendah dengan kata lain tidak elastis. Hasil uji elastisitas mie basah dengan substitusi tepung blewah $50 \%$ didapatkan presentase daya tarik sebesar $19 \%$, substitusi tepung blewah $20 \%$ didapatkan presentase daya tarik sebesar $22 \%$, dan substitusi tepung blewah $30 \%$ didapatkan presentase daya tarik sebesar $6,67 \%$. Semakin berkurang tepung terigu dalam pembuatan mie maka semakin kecil pula kandungan gluten yang ada dalam adonan mie, yang menyebabkan daya elastisitas mie berkurang. Tepung terigu memiliki kemampuan membentuk adonan yang elastisitas pada saat dibasahi dengan air karena mengandung gluten. Astawan (1999) menyatakan bahwa sifat elastisitas gluten pada adonan mie 
menyebabkan mie yang dihasilkan tidak mudah putus pada proses pencetakan dan pemasakan. Jika penggunaan terigu dikurangi dalam pembuatan mie dan diganti dengan tepung non terigu, maka akan mengakibatkan mie yang dihasilkan mudah putus.

Faktor yang mempengaruhi kekenyalan mie yaitu kandungan gluten pada tepung terigu dan kadar air pada adonan mie. Semakin banyak penambahan tepung blewah pada adonan mie, tepung terigu (kandungan glutennya) akan berkurang. Berkurangnya kandungan gluten ini akan mempengaruhi mie menjadi mudah putus. Tepung terigu yang memiliki kadar protein yang tinggi dapat mempengaruhi sifat kenyal pada mie yang dihasilkan. Semakin banyaknya kandungan gluten pada tepung terigu yang digunakan semakin tinggi pula elastisitas mie yang dihasilkan. Mie yang paling elastis ialah mie dengan bahan tepung terigu (kontrol) tanpa campuran tepung lain (Retnaningsih dan Hartayani, 2005).

Faktor-faktor yang mempengaruhi elastisitas mie ditentukan dari bahan-bahan yang digunakan, yaitu tepung terigu, penggunaan air, garam dan putih telur (Koswara, 2005). Tepung terigu banyak mengandung gluten atau protein terigu. Gluten terdiri dari gliadin dan glutenin. Gliadin mempunyai fungsi sebagai perekat dan menjadikan adonan menjadi elastis sedangkan glutenin mempunyai fungsi menjadikan adonan tetap kokoh dan menahan gas $\mathrm{CO}_{2}$ sehingga adonan dapat mengembang serta akan membentuk poripori. Berkurangnya jumlah tepung terigu didalam adonan pembuatan mie akan mengakibatkan terjadinya penurunan elastisitas pada produk mie basah (Permatasari, 2009)

Komponen terbesar pembuatan mie basah adalah tepung terigu. Tepung terigu sendiri berfungsi sebagai pembentuk struktur mie, sumber protein, dan sumber karbohidrat. Sumber protein utama pada tepung terigu yang berperan dalam proses pembuatan mie adalah gluten. Gluten adalah protein dari tepung terigu yang dibentuk dari gliadin (prolamin dalam gandum) dan glutenin. Faktor yang mempengaruhi sifat elastisitas mie basah adalah kandungan protein dalam tepung terigu, karena semakin tinggi kadar protein yang terkandung dalam tepung terigu maka semakin tinggi kemampuan menyerap air sehingga adonan mie basah tidak mudah putus dan kenyal. Gluten dapat terkoagulasi 
oleh pemanasan dalam proses pemasakan mie (Astawan, 2006).

Penggunakan tepung terigu dengan protein tinggi dimaksudkan agar mie menjadi elastis dan tahan terhadap penarikan sewaktu pada tahap produksinya. Semakin rendah penggunaan tepung terigu maka semakin sedikit air yang dapat diikat oleh gluten sehingga kadar air dalam mie basah akan menurun. Air merupakan komponen yang penting dalam pembentukan gluten. Air juga berperan sebagai media dalam percampuran garam dan pengikatan rasa, serta meningkatkan elastisitas dan mengurangi kelengketan adonan, sehingga apabila kadar air dalam mie basah menurun, maka elastisitas dan kekenyalan adonan mie basah akan berkurang (Sutomo, 2008).

\section{Uji Orgnoleptik}

\section{Rasa}

Hasil pengujian dari panelis tidak terlatih di dapatkan hasil analisis uji kesukaan mie basah dengan jumlah penggunaan tepung blewah yang berbeda dapat dilihat pada Tabel 3 berikut ini :

Tabel 3 Hasil Kesukaan Terhadap Rasa Mie Basah

\begin{tabular}{|c|c|}
\hline $\begin{array}{c}\text { Sampel } \\
\text { Tepung terigu:Tepung blewah }\end{array}$ & Rata-rata \\
\hline $50 \%: 50 \%$ & 5,2 \\
\hline $80 \%: 20 \%$ & 5,16 \\
\hline $70 \%: 30 \%$ & 4,56 \\
\hline
\end{tabular}

Rasa dapat dipakai sebagai indikator kesegaran dan penyimpangan bahan pangan. Rasa lebih banyak melibatkan pancaindera yaitu lidah, agar suatu senyawa dapat dikenali rasanya, senyawa tersebut harus dapat mengadakan hubungan dengan mikrovilus dan impuls yang terbentuk dikirimi melalui syaraf ke pusat susunan syaraf (Winarno,1997).
Rasa merupakan komponen sensori yang penting karena konsumen cenderung menyukai makanan dengan cita rasa yang enak. Berdasarkan uji sensoris yang dilakukan pada sampel mie basah dengan atribut rasa, secara umum panelis memberikan penilaian yang netral dan agak tidak suka pada sampel mie basah yang disajikan. Penilaian berkisar antara 5,2 4,56 pada ketiga sampel. Pada penelitian 
ini dalam hal rasa, panelis diberikan sampel mie basah yang telah diseduh tanpa ada bumbu atau perasa apapun dan panelis kurang menyukai dari rasa mie basah tersebut.

Penambahan tepung blewah pada penelitian pembuatan mie basah dengan tepung terigu disubtitusikan dengan tepung blewah menghasilkan mie dengan rasa yang agak manis. Rasa mie basah untuk tiap sampel beda nyata dengan sampel yang lain. Dengan adanya substitusi tepung blewah berbeda nyata pada setiap perlakuan sesuai dengan konsentrasi masing-masing.
Hal ini membuktikan bahwa adanya substitusi tepung terigu dengan menggunakan tepung blewah mempengaruhi rasa pada sampel mie basah yang dihasilkan. Tingkat kesukaan panelis terhadap rasa mie basah yang disubtitusi dengan tepung blewah kurang disukai.

\section{Warna}

Hasil pengujian dari panelis semi terlatih di dapatkan hasil analisis uji kesukaan mie basah dengan jumlah penggunaan tepung blewah yang berbeda dapat dilihat pada Tabel 4.

Tabel 4. Hasil Kesukaan Terhadap Warna Mie Basah

\begin{tabular}{|c|c|c|}
\hline $\begin{array}{c}\text { Sampel } \\
\text { Tepung terigu:Tepung } \\
\text { blewah }\end{array}$ & Perlakuan & Rata-rata \\
\hline $50 \%: 50 \%$ & $50 \%$ & 5,68 \\
\hline $80 \%: 20 \%$ & $20 \%$ & 5,92 \\
\hline $70 \%: 30 \%$ & $30 \%$ & 4,88 \\
\hline
\end{tabular}

Hasil uji sensoris pada atribut warna, secara umum panelis memberikan penilaian warna mie kering yaitu pada kisaran netral sampai agak tidak suka $(5,68-4,88)$. Berdasarkan tabel 4.4 dapat dilihat bahwa penambahan tepung blewah pada produk mie basah ternyata memberikan penilaian kesukaan panelis yang bervariasi. Pada sampel mie basah substitusi tepung blewah, menunjukkan semakin banyak tepung blewah, maka kesukaan panelis kurang, yaitu pada kisaran netral sampai agak tidak suka.

Ketiga sampel mie basah tepung blewah hasil percobaan menunjukkan adanya perbedaan warna. Perbedaan warna tersebut dipengaruhi oleh banyaknya komposisi tepung blewah pada pembuatan 
mie. Komposisi tepung blewah dalam flavonoid berpeluang membentuk warna pembuatan mie jumlahnya semakin banyak, kuning pada adonan (Sihombing, 2007). maka warna mie semakin cokelat. Berdasarkan analisa keragaman (ANOVA) Sebaliknya semakin sedikit komposisi diperoleh data $\mathrm{F}$ hitung $>\mathrm{F}$ tabel pada taraf tepung blewah atau semakin banyak tepung 5\%, maka dapat disimpulkan terdapat terigu yang digunakan maka warna mie yang dihasilkan akan kurang cokelat.

Mie basah umumnya berwarna putih kekuningan, warna ini disebabkan karena kandungan flavonoid yang terdapat pada tepung terigu . Komponen warna terlepas dari pati pada kondisi alkali sehingga perbedaan yang nyata dari 3 perlakuan.

\section{Aroma}

Hasil pengujian dari panelis tidak terlatih di dapatkan hasil analisis uji kesukaan mie basah dengan jumlah penggunaan tepung blewah yang berbeda dapat dilihat pada Tabel 5.

Tabel 5. Hasil Kesukaan Terhadap Aroma Mie Basah

\begin{tabular}{|c|c|c|}
\hline $\begin{array}{c}\text { Sampel } \\
\text { Tepung terigu:Tepung } \\
\text { blewah }\end{array}$ & Perlakuan & Rata-rata \\
\hline $50 \%: 50 \%$ & $50 \%$ & 5,8 \\
\hline $80 \%: 20 \%$ & $20 \%$ & 5,64 \\
\hline $70 \%: 30 \%$ & $30 \%$ & 6,04 \\
\hline
\end{tabular}

Dari hasil uji analisa sidik ragam diketahui hasil bahwa mie basah dengan perlakuan tepung blewah 50\%,20\%,30 memiliki nilai rata-rata 5.8 5,6,04, dan 6,04. Dengan demikian penerimaan panelis terhadap aroma mie basah masih kurang. Dari tabel 4.5 dapat dilihat bahwa subtitusi tepung blewah berpengaruh terhadap aroma yang dihasilkan. Kesukaan aroma mie basah yang dihasilkan antar masing-masing perlakuan semakin banyak subtitusi tepung blewah maka kesukaan terhadap mie basah berkurang. Aroma mie basah sangat dipengaruhi oleh bahan baku yang digunakan.

Pada penelitian ini pembuatan mie basah dengan tepung terigu disubtitusikan dengan tepung blewah. Penambahan tepung blewah pada mie menghasilkan aroma yang khas blewah. Berdasarkan grafik diatas menunjukkan bahwa penambahan blewah menghasilkan aroma yang berbeda antara 
ketiga perlakuan. Mie dengan penambahan $30 \%$ tepung blewah mendapat nilai tertinggi dibandingkan dengan perlakuan $50 \%$ dan $20 \%$.

Dari grafik diatas dapat diketahui bahwa panelis kurang menyukai aroma mie dari ketiga perlakuan. Panelis lebih menyukai aroma dari mie perlakuan tepung terigu karena panelis lebih terbiasa mengkonsumsi mie dengan bahan baku dari tepung terigu. Sedangkan Penambahan tepung blewah dapat menghasilkan aroma yang khas menimbulkan aroma blewah pada umumnya. Tepung Blewah merupakan tepung yang dihasilkan dari pengeringan blewah dan dijadikan tepung. Menurut (Subagio, 2011) hasil hidrolisis pati yang berupa monosakarida dapat menjadi bahan baku pembentukan asam-asam organik sehingga menghasilkan cita rasa tertentu yang dapat menutupi cita rasa blewah.

Aroma mie basah sangat dipengaruhi oleh bahan baku yang digunakan. Menurut Kartika (1988), aroma yaitu bau yang diukur sehingga biasanya menimbulkan pendapat yang berlainan dalam menilai kualitas aromanya. Perbedaan pendapat disebabkan tiap orang memiliki perbedaan penciuman meskipun mereka dapat membedakan aroma namun setiap orang mempunyai kesukaan yang berlainan.

\section{KESIMPULAN}

Hasil penelitian pembuatan mie basah subtitusi tepung blewah dapat disimpulkan sebagai berikut:

1. Proses pembuatan mie basah diawali dengan persiapan bahan, pencampuran bahan, pengulenan adonanan, pengistirahatan adonan, pembentukan lembaran mie, pencetakan mie dan perebusan mie.

2. Hasil uji elastisitas mie basah dengan substitusi tepung blewah 50\% didapatkan presentase elastisitas sebesar 19\%, substitusi tepung blewah $20 \%$ didapatkan presentase elastisitas sebesar $22 \%$, dan substitusi tepung blewah $30 \%$ didapatkan presentase elastisitas sebesar $6,67 \%$.Hasil uji organoleptik didapat nilai rata-rata berturut-turut untuk perlakuan $50 \%$ atribut rasa, aroma dan warna yaitu 5,2, 5,8 dan 5,88, perlakuan $20 \%$ tepung blewah 5.16, 5,64 dan 5,92 sedangkan untuk perlakuan $30 \%$ tepung blewah 4,56 , 6,04 , dan 4,88 . 
3. Mie basah dengan penambahan tepung blewah berpengaruh terhadap elastisitas mie dan tingkat kesukaan konsumen yaitu mie yang dihasilkan mudah putus, tidak elastis, dan mie kurang disukai konsumen.

\section{DAFTAR PUSTAKA}

Astawan, M. (1999). Membuat Mie Dan Bihun. Penebar Swadaya. Jakarta .

Astawan, M. (2006). Membuat Mie dan Bihun. Penebar Swadaya.Jakarta.

Direktorat Gizi Depkes RI, (1996). Daftar Komposisi Bahan Makanan. Bhratara Karya Aksara. Jakarta.

Kartika dan Bambang. (1988). Pedoman Uji Inderawi Bahan Pangan. UGM: PAU Pangan dan Gizi.

Koswara, S. (2005). Teknologi Pengolahan Mie. E bookPangan.Com.

Permatasari, S. (2009). Pengaruh Rasio Tepung Talas dan Tepung Terigu terhadap Sifat Kimia dan Organoleptik Mie Basah. Prosiding Seminar Nasional Fakultas Teknologi Pertanian, Universitas Udayana.

Retnaningsih dan Hartayani, L. (2005). Aplikasi Tepung Iles-iles (Amorphophallus konjac) sebagai Bahan Pengganti Kimia pada Mie Basah: Ditinjau dari Sifat Fisikokimiawi dan Sensoris. Laporan Penelitian. Fakultas Teknologi Pertanian, Universitas Katolik Soegijapranata. Semarang.
Sihombing, P.A., (2007). Aplikasi Ekstrak Kunyit (Curcuma domestica) Sebagai Bahan Pengawet Mie Basah. Skripsi. Fakultas Teknologi Pertanian: Institut Pertanian Bogor. Jawa Barat.

Standar Nasional Indonesia. (1992). Mie Basah. SNI 01-2987-1992. Badan Standarisasi Nasional. Jakarta

Standar Nasional Indonesia. (1992). Syarat Mutu Mie Basah. Departemen Pertanian RI

Sunarjono, H dan Ramayulis, R., (2012). Timun Suri dan Blewah. Penebar Swadaya.

Sutomo, Budi., (2008). Variasi Mie dan Pasta. PT.Kawan Pustaka. Jakarta.

Widyaningsih, Tri, D., Murtini, E.S., (2006). Alternatif Pengganti Formalin Pada Produk Pangan. Trubus Agrisarana. Jakarta

Winarno, F.G., 1997. Kimia Pangan dan Gizi. Gamedia Pustaka Utama, Jakarta. 